\title{
Influence of cryogenic cooling of cheese curd on yield and quality of semi-hard cheeses
}

\author{
Romain Richoux ${ }^{1}$, Lydie Aubert ${ }^{1}$, Marion Normand ${ }^{1}$, Patricia Privat ${ }^{2}$, \\ Dominique IBARRA ${ }^{2 *}$ \\ ${ }^{1}$ Actilait, BP 50915, 35009 Rennes Cedex, France \\ ${ }^{2}$ Air Liquide, Centre de Recherche Claude Delorme, Les Loges-en-Josas, BP 126, \\ 78350 Jouy-en-Josas, France
}

Received 13 March 2008 - Accepted 24 November 2008

\begin{abstract}
The influence of cryogenic cooling of cheese curd on the yield and the quality of semihard cheese (Trappist type) was studied. During three successive cheese manufacturing processes, the curd at moulding was separated into two aliquots: the first being directly pressed (control cheese) and the second being quickly cooled previously at $20{ }^{\circ} \mathrm{C}$ in a cryogenic cabinet (trial cheese). The cryogenic cooling of the curd slightly delayed the acidification and significantly reduced the syneresis. The increase in the cheese yield $(+4.8 \%$ at brining and $+3.8 \%$ at the end of ripening) was only due to the increase in the moisture retention. The sensory characteristics of the ripened cheeses were similar for both control and trial cheeses. The slight modifications in the melting texture and the acid taste were due to a post-acidification phenomenon that could be easily corrected by the classical operating parameters. Although stretchability was slightly increased in trial cheeses, the other functionalities were similar to those of control cheeses. Moreover, the comparison of the two experiments that were conducted with different kinetics of cooling suggests that optimisation of the cryogenic parameters could lead to a more marked increase in the cheese yield, due to higher moisture retention, and also lead to a better recovery of milk components.
\end{abstract}

cryogenic cooling / cheese yield / functionality / semi-hard cheese

摘要 - 低温冷却干酪凝块对半硬质干酪产量和质量的影响。本文研究了低温冷却干酪凝块 对半硬质干酪 (Trappist-type) 产量和质量的影响。在干酪生产过程中取 3 组凝块, 每组凝 块在模具中被平均分成两部分, 其中一部分直接压椎 (对照组), 而另一部分在压榨前先 放到 $20^{\circ} \mathrm{C}$ 的低温冷柜中快速冷却（实验组）。经低温冷却的凝块可以轻微地延迟酸化和显 著地减少凝块的脱水收缩作用。由于凝块中水分的截留量增加使得干酪的产量增加 (盐水中 产量增加了 $4.8 \%$, 最后成熟阶段产量增加了 $3.8 \%$ )。实验组和对照组成熟干酪的感 官特性相似。两组在融化特性和酸味上的微小差异是由于后酸化现象造成的, 通过 调整工艺参数很容易避免这个现象。实验组的拉伸性略有增加, 但是其他特性与对 照组相似。由于实验组和对照组采用了不同的冷却机制, 若对低温参数进一步 优化, 增加干酪中水分的截留量和提高乳成分的回收率, 有可能使干酪的产量 显著地增加。

低温冷却 / 干酪产量 / 功能性 / 半硬质干酪

* Corresponding author (通讯作者): Dominique.Ibarra@AirLiquide.com 


\begin{abstract}
Résumé - Influence d'un refroidissement cryogénique du caillé sur les rendements et la qualité de fromages à pâte pressée non cuite. L'influence d'un refroidissement cryogénique du caillé sur la qualité et les rendements de fromages à pâte pressée non cuite a été étudiée. Au cours de trois fabrications successives, le caillé au moulage était réparti en deux lots homogènes, l'un directement pressé, l'autre préalablement refroidi rapidement à $20^{\circ} \mathrm{C}$ en cellule cryogénique. Le refroidissement anticipé du caillé a conduit à un léger retard d'acidification et à une réduction significative de l'égouttage. L'augmentation des rendements fromagers $(+4.8 \%$ au saumurage, $+3.8 \%$ fin affinage) était uniquement liée à une rétention accrue d'humidité. Les caractéristiques sensorielles des fromages affinés étaient peu différentes de celles des fromages témoins. Les légères dérives de saveur acide et de texture fondante semblent directement liées à un phénomène de post acidification, facilement corrigeable par ailleurs. À l'exception d'une légère augmentation des propriétés filantes, les fonctionnalités à chaud des fromages affinés étaient similaires à celles des fromages témoins. La comparaison de deux essais se distinguant par leurs cinétiques de refroidissement laisse, par ailleurs, supposer que l'optimisation des paramètres cryogéniques pourrait conduire à des gains de rendement plus conséquents, liés à la fois à une humidité accrue et à une meilleure récupération des constituants du lait.
\end{abstract}

refroidissement cryogénique / rendement fromager / fonctionnalité / fromage à pâte pressée non cuite

\section{INTRODUCTION}

The improvement of cheese yield is a major concern for cheesemakers as the profitability of a cheese plant strongly depends on this. In the past few decades, many studies focused on cheesemilk treatment to enhance both whey protein recovery and cheese moisture [10]. Significant increase in cheese yield has been obtained using strong heat treatment of cheesemilk or the addition of denatured whey protein concentrates $[7,8]$. However, these practices have adverse effects on the sensory (texture and flavour) and functional properties (meltability and sliceability) of cheeses. Such adverse effects (e.g. poor shredding characteristics) have also been obtained when there is an increase in cheese moisture by the addition of phospholipids (e.g. buttermilk) to cheesemilk for pizza cheese manufacturing [4].

Altering the cheesemaking parameters to increase the cheese moisture is another way to improve the actual cheese yield. Besides the other well-known operating parameters, temperature plays a key role in curd syneresis [2]. A decrease in the temperature of the curd is therefore frequently used to modulate syneresis (i.e. for reduced-fat cheesemaking). Air Liquide has recently developed a cryogenic process that allows a homogeneous cooling of the cheese curd without crusting (i.e. the formation of a rigid periphery). This study is aimed to appreciate the feasibility of cryogenic cooling of the curd at moulding and its influence on cheese yield and cheese quality.

\section{MATERIALS AND METHODS}

\subsection{Cheesemaking}

Surface-ripened semi-hard cheeses (Trappist type) were manufactured from pasteurised $\left(75^{\circ} \mathrm{C}\right.$ for $\left.16 \mathrm{~s}\right)$ milk in cylindrical, jacketed, stainless steel $120-\mathrm{L}$ vats. On day $-1,100 \mathrm{~L}$ of standardised cheesemilk (fat/true protein $=1$ ) was ripened for $15 \mathrm{~h}$ at $13{ }^{\circ} \mathrm{C}$ with mesophilic O-type lactic starters (MA014, 2 U·100 L ${ }^{-1}$, Danisco, DangéSaint-Romain, France). The next day, the milk was ripened at $31.5{ }^{\circ} \mathrm{C}$ for 30 min with $0.15 \%$ of a Streptococcus thermophilus culture (PAL-ITG ST 20-82, Laboratoires 
Standa, Caen, France) grown on Marstar 412A medium (Danisco) at $42{ }^{\circ} \mathrm{C}$ until it reached $0.9 \%$ titrable acidity. The milk $(\mathrm{pH}$ 6.45) was clotted with calf rennet for $20 \mathrm{~min}$, and the gel was then cut into 4-mm curd grains. The whey-curd mixture was stirred for $10 \mathrm{~min}$. A part of the whey (30\% of milk volume) was then removed and replaced by the same amount of warm $\left(42{ }^{\circ} \mathrm{C}\right)$ water. The curd-whey mixture $\left(34.5^{\circ} \mathrm{C}\right)$ was stirred for another $15 \mathrm{~min}$ and was dipped into a pre-press vat $(1 \mathrm{kPa}$ for $20 \mathrm{~min}$ ).

The rectangular curd block was cut into 6 pieces (of about $2.5 \mathrm{~kg}$ ). Three diametrically opposed pieces were taken as control cheeses, whereas the other three pieces were taken as trial cheeses. The control cheeses were transferred into microperforated plastic moulds (of $18 \mathrm{~cm}$ diameter) and pressed (at $20 \mathrm{kPa}$ ) for $100 \mathrm{~min}$. Before moulding and pressing, the trial cheeses were cooled in the cryogenic device for about $20 \mathrm{~min}$. When the $\mathrm{pH}$ reached 5.30, the cheeses were salted for $4 \mathrm{~h}$ in a dynamic saturated brine at $14{ }^{\circ} \mathrm{C}$. These cheeses were then ripened for 21 days at $14{ }^{\circ} \mathrm{C}$ and $96 \%$ relative humidity and smeared twice a week with $5 \% \mathrm{NaCl}$ solution containing yeasts and corynebacteria.

Three replicates were made.

\subsection{Cryogenic cooling}

A forced convection cabinet (Silversas $^{\mathrm{TM}}$, Air Liquide, Paris, France) was used for the cryogenic cooling of the curd. The chamber was first cooled at $-50{ }^{\circ} \mathrm{C}$ with sprayed liquid nitrogen (eight lateral injectors) dispersed by a turbine. Raw curd pieces (without mould) were then placed into the cabinet. Nine additional injectors were placed on the top of the cryogenic cell to allow a uniform spraying of the cryogenic fluid on the surface of the curd, and then liquid nitrogen was sprayed vertically in a discontinuous mode. Thermocouples were placed both in the core and on the surface of the curd blocks, and the change in temperature during the cryogenic cooling was continuously monitored with a data acquisition system.

\subsection{Analysis}

The cheesemilk and the first and the second wheys were analysed for fat [9] and total nitrogen (TN) [11]. Non-casein nitrogen and non-protein nitrogen in cheesemilk were also determined [11].

The cheeses were analysed for total solids (TS), fat and nitrogen just before being placed in the brine. The ripened cheeses were analysed for TS, fat, calcium, $\mathrm{NaCl}$, $\mathrm{TN}, \mathrm{pH}$ 4.6-soluble nitrogen ( $\mathrm{pH}$ 4.6-SN), $12 \%$ trichloroacetic acid-soluble nitrogen (12\% TCA-SN) and 5\% phosphotungstic acid soluble nitrogen (5\% PTA-SN) as described by Berdagué et al. [1].

\subsection{Yield}

Mass, fat and protein balances at brining were controlled before the establishment of the yields. To determine the actual yield ( $\mathrm{kg}$ cheese $100 \mathrm{~kg}^{-1}$ milk), the milk mass pertaining to trial and control cheeses was estimated on the basis of the repartition of curd (ex pre-pressing vat) between control and trial cheeses. Standard yield (49\% moisture) was determined according to the methods of Maubois and Mocquot [14].

\subsection{Sensorial evaluation}

Quantitative sensory evaluations were performed by Les Maisons du Goût (Actilait, Rennes, France). Twelve trained assessors scored cheese samples on a 10-point scale for 7 texture attributes (firm, elastic, crumbly, dry, melting, granular and sticky) and 11 flavour attributes (odour intensity, taste intensity, salty, acid, sweet and bitter tastes, aroma richness, cream, boiled milk, animal and pungent aroma). 


\subsection{Functionalities}

Instrumental characterisation of the functional properties of the cheeses was measured as described by Richoux et al. [19]. To sum, the flowability was measured using a modified Schreiber test [13] and the stretchability was assessed using a method involving vertical traction of ground melted cheese $\left(82^{\circ} \mathrm{C}\right)$. Free oil of the melted cheese was measured using butyrometric analysis [19]. The browning properties were assessed by measuring the colour of the ground cheese heated in an oven at $225{ }^{\circ} \mathrm{C}$ for $6.5 \mathrm{~min}$ using a Chromameter CR 300 (Minolta, Carrièresur-Seine, France).

\subsection{Statistics}

In this study, the experimental design was made to limit the number of replicates without reduction of the statistical power. Indeed, since control and trial cheeses were not independent (twin cheeses from the same vat), paired Student tests were performed using Microsoft Excel Software. In a paired test, the null hypothesis $\left(H_{0}\right)$ : mean $($ control - trial $)=0$. These design and statistical treatments permit one to reduce the statistical influence of the variability between replicates and focus on the difference between control and trial cheeses.

\section{RESULTS AND DISCUSSION}

\subsection{Acidification and syneresis}

In contrast to control cheeses, in which the temperature remained $>30{ }^{\circ} \mathrm{C}$ during pressing, the temperature of trial cheeses ranged from $18^{\circ} \mathrm{C}$ (periphery) to $26^{\circ} \mathrm{C}$ (core) at their removal from the cryogenic chamber. However, a homogeneous temperature (about $20^{\circ} \mathrm{C}$ ) was quickly obtained (Fig. 1). Hence, as early as $40 \mathrm{~min}$ of pressing, the temperature of the trial cheeses was about $10^{\circ} \mathrm{C}$ less compared with the control cheeses.
The cooling of the trial cheeses slowed down the acidification (Fig. 2). This finding is consistent with the optimum acidification temperature of lactic acid bacteria: $30^{\circ} \mathrm{C}$ for Lactococcus lactis and $40{ }^{\circ} \mathrm{C}$ for Streptococcus thermophilus [17].

The duration required to reach the target $\mathrm{pH}$ of brining increased by $53( \pm 17) \mathrm{min}$, and $34( \pm 5)$ min of which were pertained to the cryogenic treatment. However, the $\mathrm{pH}$ at day 1 tended $(P=0.06)$ to be lower for the trial cheeses $(4.97 \pm 0.06$ vs. $5.04 \pm 0.04$ ).

The curd syneresis was reduced in the trial cheeses (Fig. 3), especially during the early stage of pressing. As a consequence, TS was significantly $(P<0.05)$ higher in the control cheeses than that in the trial cheeses from brining $\left(51.3 \pm 0.9 \mathrm{~g} \cdot 100 \mathrm{~g}^{-1}\right.$ vs. $\left.49.6 \pm 0.6 \mathrm{~g} \cdot 100 \mathrm{~g}^{-1}\right)$ to day $21(51.8 \pm$ $1.1 \mathrm{~g} \cdot 100 \mathrm{~g}^{-1}$ vs. $50.9 \pm 1.2 \mathrm{~g} \cdot 100 \mathrm{~g}^{-1}$ ). This result was expected since the temperature is known to be a key factor for syneresis. Indeed, syneresis is virtually non-existent below $20^{\circ} \mathrm{C}$. Raising of the temperature increases both porosity and rearrangement of the network of para-casein micelles and promotes syneresis. Temperature coefficient, $Q_{10}$ (the factor by which the rate changes as a consequence of increasing the temperature by $10^{\circ} \mathrm{C}$ ), around 10 was reported [2].

\subsection{Yield}

Before brining, the mass, fat and protein balances were 0.991, 1.005 and 0.996, respectively, allowing the measurement of the cheese yield. The cheese yield tended $(P=0.06)$ to be higher for trial cheeses: $12.51 \pm 0.35 \mathrm{~kg}$ cheese $\cdot 100 \mathrm{~kg}^{-1}$ milk vs. $11.94 \pm 0.11 \mathrm{~kg}$ cheese $\cdot 100 \mathrm{~kg}^{-1}$ milk (i.e. a $4.8 \%$ increase). Moisture-adjusted yield, and fat and protein recoveries were similar $(P>0.05)$ for control and trial cheeses (data not shown), suggesting that the yield increase was only due to the moisture increase. 


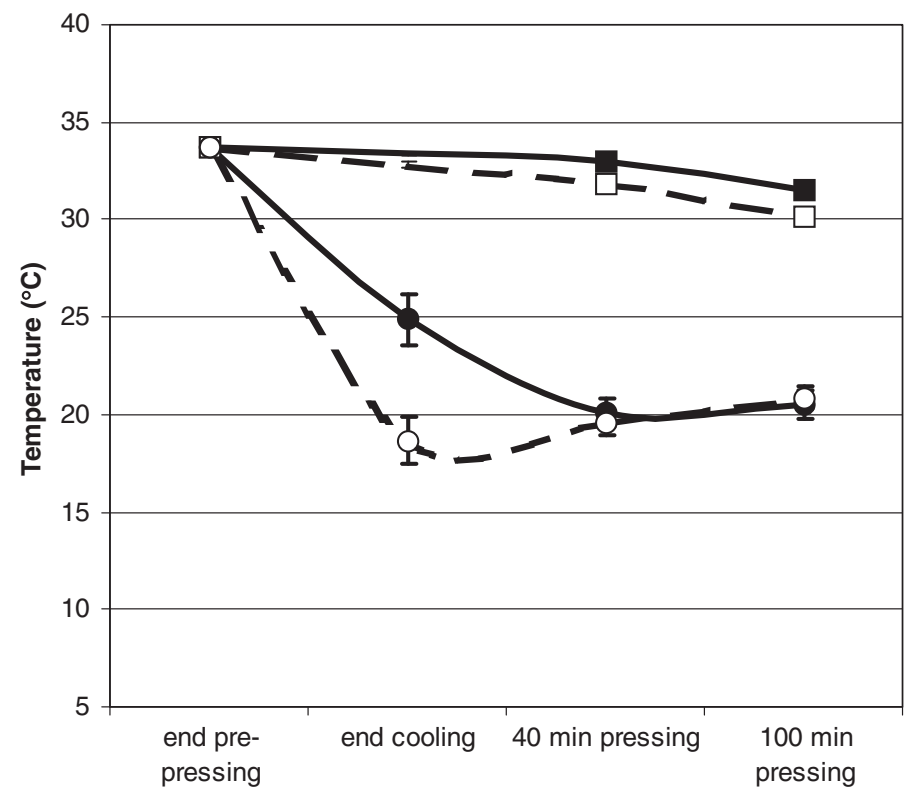

Figure 1. Change in temperature during pressing and acidification of cheeses (mean value, errorbars: standard deviation, $n=3$ ). $\mathbf{\square}$, core of the control cheeses; $\square$, periphery of the control cheeses; -, core of the trial cheeses; $O$, periphery of the trial cheeses.

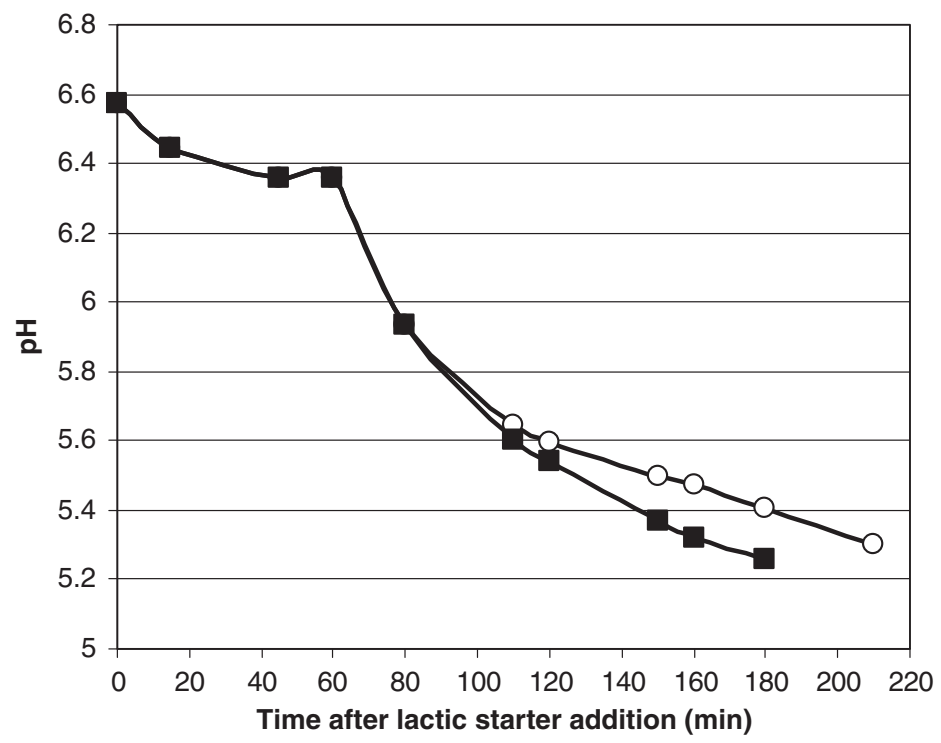

Figure 2. Acidification in the core of the control $(\mathbf{\square})$ and the trial cheeses $(O)$ (mean values, $n=3)$. 


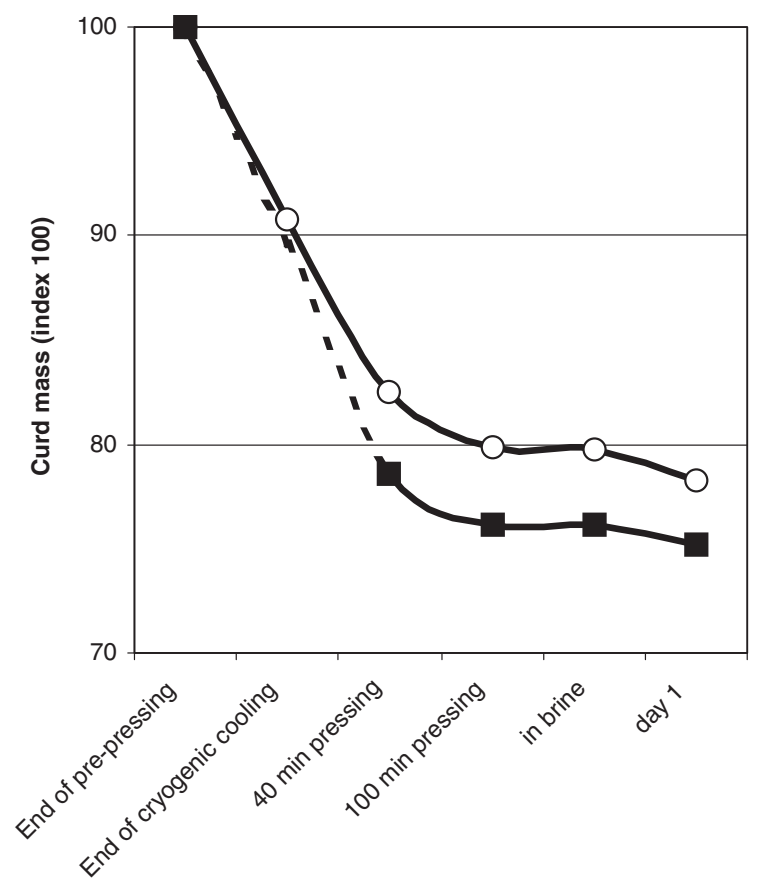

Figure 3. Change in curd mass during pressing and acidification of the control ( $\mathbf{\square})$ and the trial cheeses $(O)$ (mean values, $n=3$ ); index 100 is the curd mass at the end of pre-pressing.

Weight loss of control and trial cheeses was similar during brining (1.5\%) but was higher during ripening for trial cheeses $(P=0.04): 0.6 \pm 0.17 \%$ vs. $0.15 \pm 0.11 \%$. Finally, a $3.8 \%$ increase in the actual yield of ripened cheeses was obtained with cryogenic cooling $(11.8 \pm 0.15 \mathrm{~kg}$ cheese $\cdot 100 \mathrm{~kg}^{-1}$ milk vs. $12.2 \pm 0.39 \mathrm{~kg}$ cheese $\cdot 100 \mathrm{~kg}^{-1}$ milk $P=0.08$ ).

\subsection{Composition of the ripened cheeses}

Trial cheeses had a significantly $(P<0.05)$ lower TS $\left(50.9 \pm 1.2 \mathrm{~g} \cdot 100 \mathrm{~g}^{-1}\right.$ Vs. $\left.51.8 \pm 1.1 \mathrm{~g} \cdot 100 \mathrm{~g}^{-1}\right)$ and higher moisture in non-fat substance $(66.3 \%$ vs. $65.4 \%$ ). The mineralisation of trial cheeses was also reduced $(P<0.001)$, since calcium content $\left(0.55 \pm 0.01 \mathrm{~g} \cdot 100 \mathrm{~g}^{-1}\right.$ cheese vs.
$0.58 \pm 0.02 \mathrm{~g} \cdot 100 \mathrm{~g}^{-1}$ cheese) and calcium/non-fat solids $(2.27 \pm 0.03 \%$ vs. $2.18 \pm 0.03 \%$ ) were lower. The dynamics of syneresis and acidification explain the lower calcium content of trial cheeses. After $30-40 \mathrm{~min}$ of the end of pre-pressing, control and trial cheeses had a similar $\mathrm{pH}$ value but with a different TS. Further syneresis corresponded to $2.4 \%$ of the initial curd weight for control cheeses vs. $11 \%$ for trial cheeses. More calcium was probably expelled in the trial cheese whey during this late drainage.

The control and the trial cheeses had identical mean values for fat in dry matter $(50.8 \pm 0.3 \%), \mathrm{NaCl}\left(1.7 \pm 0.2 \mathrm{~g} \cdot 100 \mathrm{~g}^{-1}\right)$, $\mathrm{pH} \quad 4.6-\mathrm{SN} / \mathrm{TN} \quad(19.9 \pm 0.3 \%), \quad 12 \%$ TCA-SN/TN $(11.2 \pm 0.2 \%)$ and $5 \%$ PTA-SN/TN $(2.2 \pm 0.1 \%)$. The lower $\mathrm{pH}$ in trial cheeses could also explain similar 
Table I. Functionalities of the ripened cheeses $(n=3)$.

\begin{tabular}{lccc}
\hline Functionalities & Control cheese & Trial cheese & $P$ values \\
\hline Stretchability $(\mathrm{mm})$ & 46 & 95 & 0.001 \\
Flowability (index) & 3.66 & 3.55 & 0.322 \\
Oiling off $\left(\mathrm{g} \cdot 100 \mathrm{~g}^{-1}\right)$ & 12.0 & 12.7 & 0.369 \\
Browning (a.u.) & & & \\
$\quad L^{*}$ & 58.5 & 60.0 & 0.138 \\
$a^{*}$ & 16.4 & 15.8 & 0.097 \\
$b^{*}$ & 39.8 & 41.1 & 0.311 \\
\hline
\end{tabular}

proteolysis observed in control and trial cheeses despite their differences in moisture content. Indeed, primary proteolysis is well known to be enhanced by higher moisture content but decreased by lower $\mathrm{pH}$ [20]. In such high-moisture semi-hard cheeses, the breakdown of the $\alpha s_{1}$-casein (mainly due to chymosin) occurs very early and is not $\mathrm{pH}$ dependent. In contrast, the $\beta$-casein breakdown due to plasmin is rather limited and is strongly dependent on the $\mathrm{pH}$ of the cheese [3].

The similar salt intake observed in control and trial cheeses can be explained by the higher moisture in trial cheeses and the higher temperature of control cheeses when they were placed in the brine (Fig. 1). Indeed, both parameters are well known to enhance the salt intake in cheese [6] and probably offset each other.

\subsection{Sensorial analysis}

Trial cheeses were significantly $(P<0.05)$ less bitter (3.2 vs. 4.2$)$ and more salty (4.1 vs. 3.5). The texture of trial cheeses also tended $(0.05<P<0.10)$ to be slightly less melting (5.7 vs. 6.2) and crumbly (1.4 vs. 2.0$)$ and more sticky (6.3 vs. 6.0). Acid taste also tended to be higher (3.8 vs. 3.2). Most of these modifications, especially the melting texture and the acid taste, can be linked to the lower $\mathrm{pH}$ of trial cheeses. They could easily be restored by well-known operating parameters, such as by the increase in water addition during curd washing [21].

\subsection{Functional properties}

As shown in Table I, the functional properties of control and trial cheeses were very similar except for stretchability, which was twice as high for trial cheeses. This finding was unexpected because both demineralisation and $\mathrm{pH}$ decrease are known to reduce cheese stretchability $[5,12]$. However, the mean values of stretchability were low for both trial and control cheeses. Their difference was close to the repeatability of the method [19] and would probably not be detected by sensorial analysis (Actilait, unpublished results).

The red component $\left(a^{*}\right)$ of the ground cheese also tended to be weaker for trial cheeses. Despite higher moisture content and lower calcium content, the trial cheeses had similar flowability to the control cheeses. The lower $\mathrm{pH}$ could explain this phenomenon [12].

\subsection{Effect of the kinetic of cooling}

The parameters of the cryogenic cooling were modified after the first set of experiments (by adjusting the frequency and the duration of $\mathrm{N}_{2}$ injections) to reduce the thermal heterogeneity between the core 
and the periphery of the curd blocks. In the following experiments, the trial cheeses were cooled more quickly $(28 \mathrm{~min}$ vs. $40 \mathrm{~min})$, albeit to a lesser extent $\left(27^{\circ} \mathrm{C}\right.$ in the core vs. $25.5^{\circ} \mathrm{C}$ ). Although these results were not replicated, interesting observations can be taken from the comparison of the first and the second experiments that had similar in-vat syneresis (TS: $41.9 \mathrm{~g} \cdot 100 \mathrm{~g}^{-1}$ vs. $42.6 \mathrm{~g} \cdot 100 \mathrm{~g}^{-1}$ at the end of the pre-pressing).

In the first experiment (lower rate of cooling and slightly lower in-vat syneresis), the cryogenic cooling increased the actual yield at brining more markedly: $+8.5 \%$ vs. $+4.4 \%$ for the second experiment. Moreover, in the first experiment, the moistureadjusted yield increased from about $12.0 \mathrm{~kg} \cdot 100 \mathrm{~kg}^{-1}$ (control cheese) to $12.4 \mathrm{~kg} \cdot 100 \mathrm{~kg}^{-1}$ (trial cheese), i.e. a $3.3 \%$ increase in the moisture-adjusted yield. This result is consistent with the slight increase in both non-fat solid (33.8\% vs. $32.5 \%$ ) and fat $(94.2 \%$ vs. $90.5 \%)$ recovery observed in this trial. Hence, the increase in the actual yield observed in Experiment 1 not only seems to be solely due to a higher moisture retention, but also due to the better recovery of the milk components. This suggests that the optimisation of the cryogenic parameters could lead to a more marked increase in the cheese yield than the mean value observed for the three replicates.

Moreover, the sensory characteristics of the trial cheeses were closer to those of the control cheeses, probably because of their closer $\mathrm{pH}(\Delta=0.03$ vs. 0.12 unit at day 1).

\section{CONCLUSIONS}

These results show that the cryogenic cooling of the curd increased the cheese yield without major alteration in the cheese quality. This contrasts with the use of highheat-treated milk or with the addition of heat-denatured whey proteins $[5,15]$ that markedly impair functional properties and sensorial characteristics.

Our results of higher moisture content are similar to those obtained with the use of capsular (or ropy) strains of lactic acid bacteria [18] or with the use of small milk fat globule-enriched milk by microfiltration [16]. However, the use of exopolysaccharide-producing strains limits the choice of the lactic starters and requires large inocula of bulk starters. The microfiltration process is rather expensive. In contrast, the cryogenic cooling of curd is a less-expensive technique that requires little investment and can be easily adapted into the existing cheesemaking lines.

\section{REFERENCES}

[1] Berdagué J.L., Grappin R., DelacroixBuchet A., Chaillet B., Pidoux P., Caractérisation de l'emmental « Grand-Cru » français. I. Composition physico-chimique, Lait 70 (1990) 1-14.

[2] Dejmek P., Walstra P., The syneresis of rennet coagulated milk, in: Fox P.F., McSweeney P., Cogan T.M., Guinee T.P. (Eds.), Cheese: Chemistry, Physics and Microbiology, vol. 1, General Aspects, 3rd edn., Elsevier, London, UK, 2004, pp. 71-104.

[3] Fournier S., Les paramètres de la fabrication des fromages à pâte pressée non cuite. Études sur un fromage modèle. Étude Actilait-ITG DC 1992/10/B, Actilait, Bourgen-Bresse, France, 1992.

[4] Govindasamy-Lucey S., Lin T., Jaeggi J.J., Martinelli C.J., Johnson M.E., Lucey J.A., Effect of type of concentrated sweet cream buttermilk on the manufacture, yield, and functionality of pizza-cheese, J. Dairy Sci. 90 (2007) 2675-2688.

[5] Guinee T.P., The functionality of cheese as an ingredient: a review, Aust. J. Dairy Technol. 57 (2002) 79-91.

[6] Guinee T.P., Fox P.F., Salt in cheese: physical, chemical and biological aspects, in: Fox P.F., McSweeney P., Cogan T.M., Guinee T.P. (Eds.), Cheese: Chemistry, Physics and Microbiology, vol. 1, General Aspects, 3rd edn., Elsevier, London, UK, 2004, pp. 207-260. 
[7] Guyomarc'h F., Formation of heat-induced protein aggregates in milk as a means to recover the whey protein fraction in cheese manufacture, and potential of heat-treating milk at alkaline $\mathrm{pH}$ values in order to keep its rennet coagulation properties. A review, Lait 86 (2006) 1-20.

[8] Hinrichs J., Incorporation of whey protein in cheese, Int. Dairy J. 11 (2001) 495-503.

[9] International Dairy Federation, Milk-Determination of Fat Content, Standard No. 105, IDF, Brussels, Belgium, 1981.

[10] International Dairy Federation, Cheese Yield and Factors Affecting its Control, Special Issue 94-2, IDF, Brussels, Belgium, 1994.

[11] International Dairy Federation, Determination of Nitrogen Content, Standard No. 20, IDF, Brussels, Belgium, 2001.

[12] Kindstedt P.S., Zielinski A., Almena-Aliste M., Ge M., A post manufacture method to evaluate the effect of $\mathrm{pH}$ on Mozzarella cheese characteristics, Aust. J. Dairy Technol. 56 (2001) 202-207.

[13] Kosikowski F., Testing melting quality of process cheese by standard L.D. Schreiber Int., in: Kosikowski F. (Ed.), Cheese and Fermented Milk Foods, 2nd edn., Edwards Brothers Inc., Ann Arbor, MI, USA, 1997, pp. 405-406.

[14] Maubois J.L., Mocquot G., Comment ramener à la même teneur en matière sèche des fabrications de fromage en vue de comparer les rendements respectifs du lait en fromage, Rev. Lait Fr. 239 (1967) 15-18.

[15] Mead D., Roupas P., Effect of denatured whey proteins on chemical composition and functionality of pizza cheese, Aust. J. Dairy Technol. 56 (2001) 19-23.

[16] Michalski M.C., Camier B., Gassi J.Y., Briard-Bion V., Leconte N., Famelart M.H., Lopez C., Functionality of smaller vs. control native milk fat globules in Emmental cheese manufactured with adapted technology, Food Res. Int. 40 (2007) 191-202.

[17] Parente E., Cogan T.M., Starter cultures: general aspects, in: Fox P.F., McSweeney P., Cogan T.M., Guinee T.P. (Eds.), Cheese: Chemistry, Physics and Microbiology, vol. 1, General Aspects, 3rd edn., Elsevier, London, UK, 2004, pp. 123-148.

[18] Perry D.B., McMahon D.J., Oberg C.J., Effect of exopolysaccharide-producing cultures on moisture retention in low fat Mozzarella cheeses, J. Dairy Sci. 80 (1997) 799-805.

[19] Richoux R., Roset G., Famelart M.H., Kerjean J.R., Diversité de quelques propriétés fonctionnelles à chaud de l'Emmental français, Lait 81 (2001) 547-559.

[20] Upadhyay V.K., McSweeney P., Magboul A.A.A., Fox P.F., Proteolysis in cheese during ripening, in: Fox P.F., McSweeney P., Cogan T.M., Guinee T.P. (Eds.), Cheese: Chemistry, Physics and Microbiology, vol. 1, General Aspects, 3rd edn., Elsevier, London, UK, 2004, pp. 391-433.

[21] van den Berg G., Meijer W., Düsterhoft E.M., Smit G., Gouda and related cheeses, in: Fox P.F., McSweeney P., Cogan T.M., Guinee T.P. (Eds.), Cheese: Chemistry, Physics and Microbiology, vol. 2, Major Cheese Groups, 3rd edn., Elsevier, London, UK, 2004, pp. 103-140. 